\title{
Wind Climate of the Whitehorse Area
}

\author{
JEAN-PAUL PINARD ${ }^{1}$
}

(Received 21 March 2006; accepted in revised form 23 January 2007)

\begin{abstract}
Measurements from Whitehorse upper-air and nearby mountaintop stations were analyzed with a focus on wind energy development in the region. Fifty years of measurements indicate the region has become warmer and windier. Measurements at the upper-air station have shown increases of $2.7^{\circ} \mathrm{C}$ for surface temperature and $1 \mathrm{~m} \mathrm{~s}^{-1}$ for mid-valley winds over the past 50 years (1956-2005). The winters have warmed more dramatically than the summers. Winter temperature inversions have become shallower, and a mid-valley winter jet has become a predominant feature. Wind data for $2001-05$ indicate that a minimum annual mean wind speed of $6 \mathrm{~m} \mathrm{~s}^{-1}$ begins at about $150 \mathrm{~m}$ above the Whitehorse valley floor, or $850 \mathrm{~m}$ above sea level. At this elevation and higher, wind speeds reach a maximum in December and a minimum in July. The predominant wind direction above the mountaintops was from the southwest, while stations within the Whitehorse Valley recorded winds from the south-southeast. Stations that were more exposed to the southwest reported more predominant winds from this direction. An analysis of the relationship between geostrophic and valley winds concluded that, relative to winds aloft, valley winds were as strong in parallel valleys as they were in perpendicular valleys. The pressure gradients associated with the winds aloft were the dominant forcing mechanism for winds in a perpendicular valley. Geostrophic winds that were parallel to the valley forced the valley winds along the same direction through a downward momentum transport. Wintertime inversions suppress the downward momentum transport, but pressure-driven winds are only indirectly modulated by stratification (because of turbulent friction, which is likely to be suppressed by stable stratification) and so are less sensitive to that factor. Further investigation of wind energy potential is recommended for hills within the valleys, particularly in areas well exposed to southwest winds.
\end{abstract}

Key words: Yukon, mountain, upper-air, wind energy, climate change, geostrophic, valley

RÉSUMÉ. Des mesures prises dans la haute atmosphère de Whitehorse et dans les stations de sommets de montagnes environnantes ont été analysées en portant une attention particulière à la formation de l'énergie éolienne dans la région. D'après des mesures prélevées sur une période de 50 ans, la région est maintenant plus chaude et plus venteuse qu'elle ne l'était auparavant.

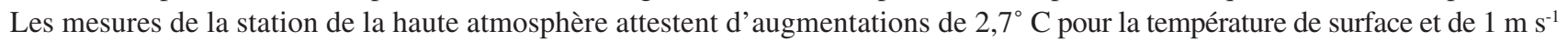
pour les vents en milieu de vallée au cours des 50 dernières années (1956-2005). Les hivers se sont réchauffés de façon plus spectaculaire que les étés. Les inversions de températures d'hiver sont devenues plus minces, tandis qu'un jet d'hiver en milieu de vallée est maintenant une caractéristique prédominante. Les données relatives au vent pendant les années 2001 à 2005 indiquent une vitesse du vent moyenne annuelle minimale de $6 \mathrm{~m} \mathrm{~s}^{-1}$ commençant à environ $150 \mathrm{~m}$ au-dessus du plancher de la vallée de Whitehorse, soit à $850 \mathrm{~m}$ au-dessus du niveau de la mer. À cette altitude et au-dessus de celle-ci, les vitesses du vent atteignent leur maximum en décembre et leur minimum en juillet. La direction prédominante du vent au-dessus des sommets de montagnes provenait du sud-ouest, tandis qu'aux stations de la vallée de Whitehorse, les vents venaient du sud et du sud-est. Les stations les plus exposées au sud-ouest ont signalé plus de vents prédominants provenant de cette direction. L'analyse de la relation entre les vents géostrophiques et les vents de la vallée a permis de conclure que relativement aux vents d'en haut, les vents de la vallée étaient aussi forts dans les vallées parallèles que dans les vallées perpendiculaires. Les gradients de pression associés aux vents d'en haut constituaient le mécanisme de la force dominante pour les vents d'une vallée perpendiculaire. Les vents géostrophiques qui étaient parallèles à la vallée forçaient les vents de la vallée à adopter la même direction en raison d'un transport au mouvement descendant. Les inversions d'hiver supprimaient le transport au mouvement descendant, mais les vents obéissant à la pression ne sont qu'indirectement modulés par la stratification (en raison du frottement turbulent, ce qui est susceptible d'être supprimé par la stratification stable) et par conséquent, ils sont moins sensibles à ce facteur. Nous recommandons qu'une enquête plus poussée soit réalisée sur l'énergie éolienne naturelle des collines des vallées, particulièrement dans les endroits bien exposés aux vents du sud-ouest.

Mots clés : Yukon, montagne, haute atmosphère, énergie éolienne, changement climatique, géostrophique, vallée

Traduit pour la revue Arctic par Nicole Giguère.

\footnotetext{
${ }^{1}$ Department of Earth and Atmospheric Sciences, University of Alberta, Edmonton, Alberta T6G 2E3, Canada; present address: 703 Wheeler Street, Whitehorse, Yukon Y1A 2P6, Canada; jpp@ northwestel.net

(C) The Arctic Institute of North America
} 


\section{INTRODUCTION}

While the southern Yukon is energized mainly by hydro power, the territory's growing energy demand and the limited wintertime hydro availability are increasing the need for diesel-electric generation during the coldest months of the year. Diesel is an imported, non-renewable fuel that emits carbon dioxide gases and locally hazardous pollutants. The fossil fuel is transported from long distances and stored, adding further environmental risks. These drawbacks, combined with the rising cost of fossil fuel, are creating opportunities for wind energy. Wind energy complements hydro power because mountaintop winds increase markedly in winter, when the hydro-electric storage capacity is at a minimum. Two large commercial-scale wind turbines were installed on Haeckel Hill near Whitehorse in 1993 and 2000. Together, they have a capacity of $850 \mathrm{~kW}$ and have been feeding 150 residences year round. With the growing energy demand, new locations with greater wind potential are needed to accommodate the expansion of wind energy in the Yukon. Figure 1 shows a map of Whitehorse and its mountainous vicinity. The map also shows the power lines of the main electrical grid, along which wind energy development should focus. The terrain in the Whitehorse area ranges from 600 to $2500 \mathrm{~m}$ above sea level (ASL) with valleys oriented in roughly two directions: southeast to northwest (Whitehorse Valley) and east to southwest (Takhini River valley).

The most relevant criterion for new wind energy sites is that annual mean wind speed should exceed a threshold of $6 \mathrm{~m} \mathrm{~s}^{-1}(21.6 \mathrm{~km} / \mathrm{hr})$. From Pinard (2005), it is apparent that valley bottoms have less wind energy potential than mountaintops. However, there are compelling reasons to find good windy sites at the lowest elevations possible. Haeckel Hill and the mountaintop sites are all prone to heavy rime icing in the winter. Anti-icing technology has been applied to the blades of the Haeckel Hill turbines, but it is desirable to avoid this rather expensive modification. Icing occurs during times when clouds form on Haeckel Hill (Maissan, 2001), and anecdotal evidence shows less frequent cloudiness at lower elevations and perhaps less icing. Finding a windy hilltop within a valley requires an understanding of the predominant wind flows within and above the mountainous region.

According to Klock et al. (2001), the mean summer flows aloft (500 mbar) over the southern Yukon are southwesterly. In the winter, they are stronger and more westerly. While the winds at the Whitehorse airport and on Haeckel Hill were primarily from the south-southeast following the valley (Pinard, 2005), Baker (1991) found that the prevailing wind direction was south-southeast at $1220 \mathrm{~m} \mathrm{ASL}$ and shifted by $40^{\circ}$ clockwise to southsouthwest at $1830 \mathrm{~m}$ ASL. The relationship between winds aloft and those within the valley can be explained by a number of forcing mechanisms, two of which may be more relevant to wind energy applications in a mountainous terrain such as the Whitehorse area. The two are forced channeling of the downward momentum transport and pressure-driven channeling. These conditions are described in greater detail by Gross and Wippermann (1987) in their study of the Rhine Valley and by Whiteman and Doran (1993) for the Tennessee Valley.

Similar veering of winds was observed at Burwash Landing in the Kluane Valley, $200 \mathrm{~km}$ west of Whitehorse, in a 1977-78 winter minisonde study reported by Faulkner (1981) and Nikleva $(1979,1984)$. The Kluane Valley is oriented northwest to southeast. In this study, low-level valley jets (local maxima in wind speed) were observed and typically occurred from the southeast at mid-height within the valley when winds aloft were from the southwest. The observed jets were 500 to $600 \mathrm{~m}$ below the top of the temperature inversion (height of maximum temperature). When the winds aloft followed the valley from the southeast, there was vertical momentum transfer into the valley (winds aloft mixing downward into the valley through turbulence), and no jet appeared. Nikleva (1984) noted similar results in a study at Beaver Creek, $150 \mathrm{~km}$ to the northwest, but the phenomenon was not as pronounced as the valley there was wider. Along the same valley system in Alaska, a study by Mitchell (1956) also described strong east-southeast winter winds similar to those at Burwash Landing. Valley jets may have important implications for wind energy in the Whitehorse region.

Although much research has investigated the forcing mechanisms of the low-level jet, no universally applicable paradigm has emerged. It is safe to say, however, that the phenomenon is closely associated with the occurrence of an inversion, which inhibits vertical momentum transfer and so decreases turbulent friction. The maximum wind speed (i.e., the nose of the jet) most often occurs below the top of the inversion. The existence of valley/ridge terrain (with associated pressure gradients and non-uniform cooling) further complicates the explanation (and modeling) of the low-level jet.

According to Wahl et al. (1987), the inversion cap (level of maximum temperature) in the Whitehorse Valley has typically been just below the mountaintops (2000 m ASL) in the winter, but shallower inversions also occurred during summer nights. No valley jets have been reported in the Whitehorse Valley; however, Wahl noted that supergradient winds existed in mountain passes oriented along the prevailing pressure gradients.

While the above conditions may be relevant in the Whitehorse Valley, it is important to note that they might change with time. Evidence indicates that the Yukon's climate is warming up and becoming windier. The Intergovernmental Panel on Climate Change indicated that the climate in the Yukon has been warming by 0.2 to $0.6^{\circ} \mathrm{C}$ per decade (IPCC, 1998). Dormann and Woodin (2002) described climate models predicting trends in which winter temperatures are increasing more dramatically than summer temperatures. Graham and Diaz (2001) indicate that the winter cyclones have intensified over the North Pacific Ocean since 1948, causing increased wind speeds over the 
ocean surface. Hartmann and Wendler (2005) note that mean wind speeds in Alaska have increased because of the increasing difference in sea level pressure between the western North Pacific and western Canada. This change has also increased southerly winter winds, bringing more warm moisture from the Pacific to Alaska and Yukon.

The Whitehorse Valley wind climate is studied here using 50 years of wind and temperature data (weather balloon, radiosonde, sounding) from the local upper-air station. The upper-air measurements are also compared to those from local surface stations to construct an area wind climate model. The upper-air data is a twice-daily set of vertical profiles of horizontal wind information that may serve to answer some of the more relevant questions:

- At what elevations will threshold annual mean wind speeds for cost-efficient wind-energy production be attained? (i.e., where do annual mean speeds exceed $6 \mathrm{~m} \mathrm{~s}^{-1}$ ?)

- How do the wind speed and the prevailing wind direction change with elevation and location?

- How are inversions factored into the above phenomena?

- How does the wind climate change with the seasons?

- Has the wind climate changed over the years?

Pinard et al. (2005) attempted to answer some of these questions using numerical modeling techniques, but with only a partial understanding of the relationship between the winds and the mountainous topography. The present study of Whitehorse upper-air data is intended to add to the existing knowledge base used to understand wind climate trends and patterns in the territory and other mountainous regions.

\section{THE MONITORING STATIONS}

The surface stations used in this study are a combination from several programs of the Yukon Government (YG), the Boreal Alternative Energy Centre (BAEC), and the Meteorological Service of Canada (MSC; the Whitehorse airport and upper-air stations). The YG surface stations, Nursery and Mount Sima, were established for forest fire purposes, and the Laberge and Fish stations were part of a community wind resource assessment program. The BAEC surface stations, Haeckel Hill, Mount Sumanik, and Flat Mountain (see Fig. 1), were all mountaintop sites, and their measurements (in contrast to the other surface stations) exhibited commercially feasible wind speeds. These three sites are given more attention in this study and are correlated against the measurements of the upper-air station.

All of the surface stations measured wind speed and direction with one- or two-second sampling rates averaged across 10-minute intervals (except the Whitehorse airport station, which had one-hour samplings). The monitoring from the YG sites covers periods of one to three years over the last ten years. Data from the Whitehorse airport, compiled for the period 1955-80, come from the Atmospheric Environment Service (AES, 1982), now the
Meteorological Service of Canada (MSC). Nearly all of these stations measured winds at $10 \mathrm{~m}$ above ground level (AGL hereafter). The period mean wind speed for each site was projected to a new wind speed at $30 \mathrm{~m}$ AGL using the logarithmic law and estimates of local surface roughness. The combined error in measurement, period variability, and vertical projection for these stations is about $20 \%$.

At the three BAEC sites, measurements were taken for at least one year from 1991 to 1995, but these measurements were contaminated to some extent in the wintertime by mountaintop rime icing conditions. Approximately one year of ice-free wind speed and direction measurements were available for creating wind roses. For correlation with the upper-air measurements, two periods of uncontaminated measurements were extracted: June-August 1992 (88 days) for Mount Sumanik and Flat Mountain, and August-October 1994 (61 days) for Mount Sumanik and Haeckel Hill. The combined error in measurement, period variability, and vertical projection for the BAEC stations is a maximum of about $10 \%$.

The sounding data (radiosonde) used in this study are administered by NOAA (The National Oceanic and Atmospheric Administration, U.S. Department of Commerce, which administers sounding data for North America). Sounding data from other northern locations are briefly analyzed to compare trends with the Whitehorse analysis. Most of these soundings begin in the mid-1950s. For Whitehorse, the soundings date back to July 1955. The upper-air station was first established by the U.S. military during the Second World War and was taken over by the MSC in 1946. As of 1948, it was located at the Whitehorse International Airport on the east side of the runway $\left(60.7157^{\circ} \mathrm{N}, 135.0626^{\circ} \mathrm{W}\right)$, in a field well exposed to both south and north. It was at $698 \mathrm{~m} \mathrm{ASL}$ and well centralized in the valley. This location was also near the present-day location of the Whitehorse airport wind station. In 1962, the upper-air station was moved $950 \mathrm{~m}$ southwest across to the west side of the runway $\left(60.7106^{\circ} \mathrm{N}, 135.07668^{\circ} \mathrm{W}\right.$, $704 \mathrm{~m}$ ASL). In 1996, the station was moved to its present location $\left(60.7330^{\circ} \mathrm{N}\right.$ and $\left.135.0979^{\circ} \mathrm{W}, 704 \mathrm{~m} \mathrm{ASL}\right)$, about $2.7 \mathrm{~km}$ northwest of its original airport site. It is in a small field, surrounded by a few buildings and sheltered by a small, forested hill about $300 \mathrm{~m}$ to the southeast.

A question arises as to how much the three moves affected wind speed measurements in the valley. Figure 1 shows a $10 \mathrm{~km}$ diameter circle encompassing the three sites (white circle-dots) that were home to the upper-air stations. The present site is northwest of the other two. Each balloon typically rises from the valley bottom to the mountaintop elevation (704 to $2200 \mathrm{~m} \mathrm{ASL}$ ) in about five minutes. The balloon climbs at a rate of approximately $5 \mathrm{~m} \mathrm{~s}^{-1}$, while its maximum mean horizontal speeds rarely exceed $10 \mathrm{~m} \mathrm{~s}^{-1}$ at heights below $2200 \mathrm{~m}$ ASL. Therefore, the balloon is estimated to travel a maximum horizontal distance of $3 \mathrm{~km}$ in any given direction on its trajectory from surface to mountaintop.

The upper-air balloons have been released every 12 hours daily (approximately 3:00 AM and 3:00 PM Pacific 


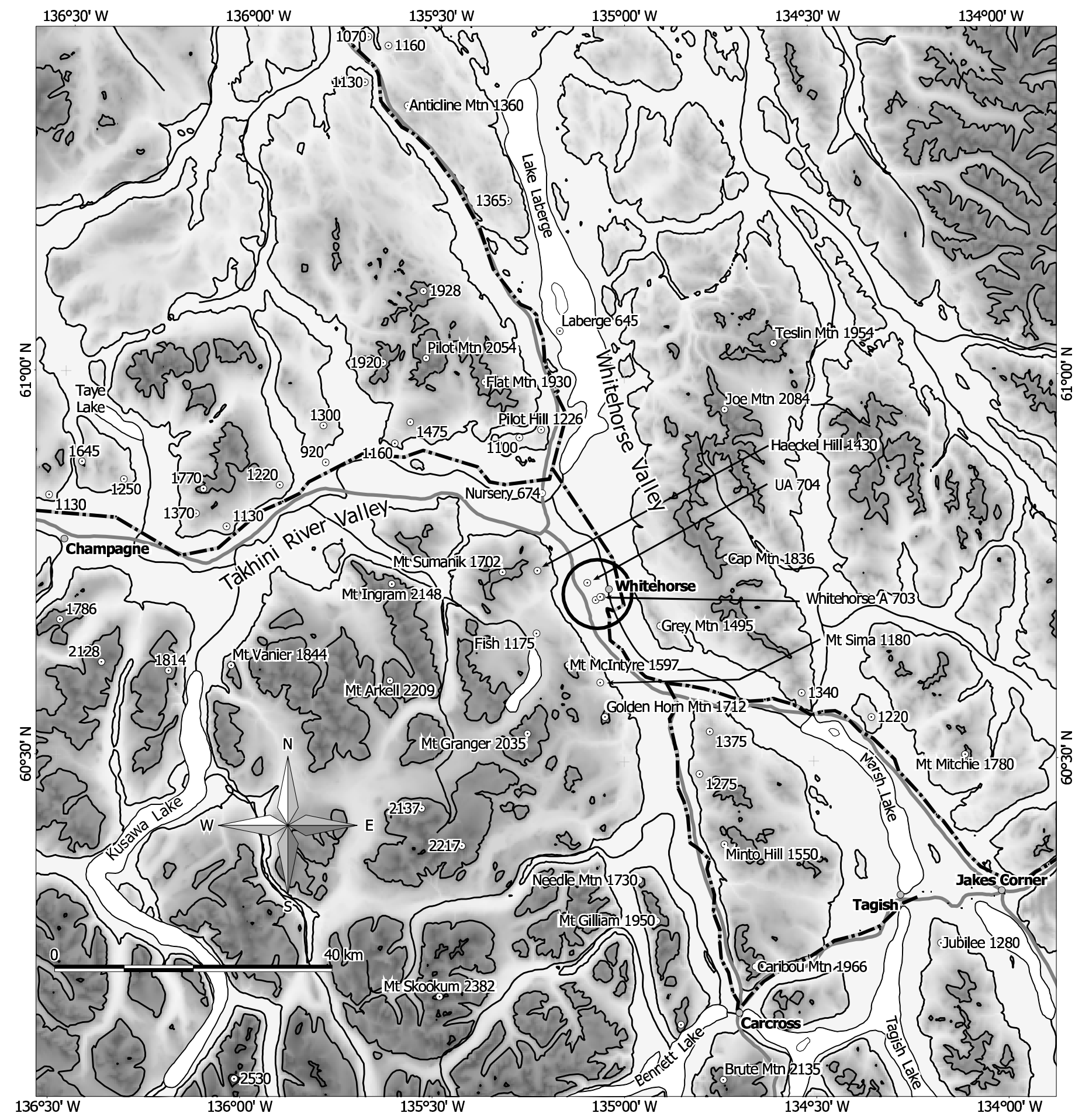

FIG. 1. Map of the Whitehorse area, with contours at 900, 1500, and $2100 \mathrm{~m}$ ASL. Dash-and-dot lines indicate the approximate location of the power lines. Local peaks, isolated hills, and wind monitoring sites are identified by circle-dots and accompanying elevations (in metres ASL). The three successive locations of the three upper-air stations are within the circle. The first two locations were near the Whitehorse A station, and the present location is identified as "UA."

Standard Time) and occasionally at six-hour intervals. In the early part of the NOAA data set, the occurrences of temperature and wind measurements are vertically distributed in the lower troposphere. In each sounding, however, the measurements do not appear consistently at fixed elevations; they are tied to mandatory pressure levels. Figure 2 shows two profiles of wind measurements. The one for 1956-60 shows an increased number of measurements at the surface, at 800 to $1000 \mathrm{~m} \mathrm{ASL}$, and roughly every $500 \mathrm{~m}$ above this. The $2001-05$ profile shows wind measurements concentrated at $300 \mathrm{~m}$ intervals with very few measurements in between. The total number of wind speed measurements increased by $73 \%$ between the two periods. This increase had occurred by about 1988 . Records 


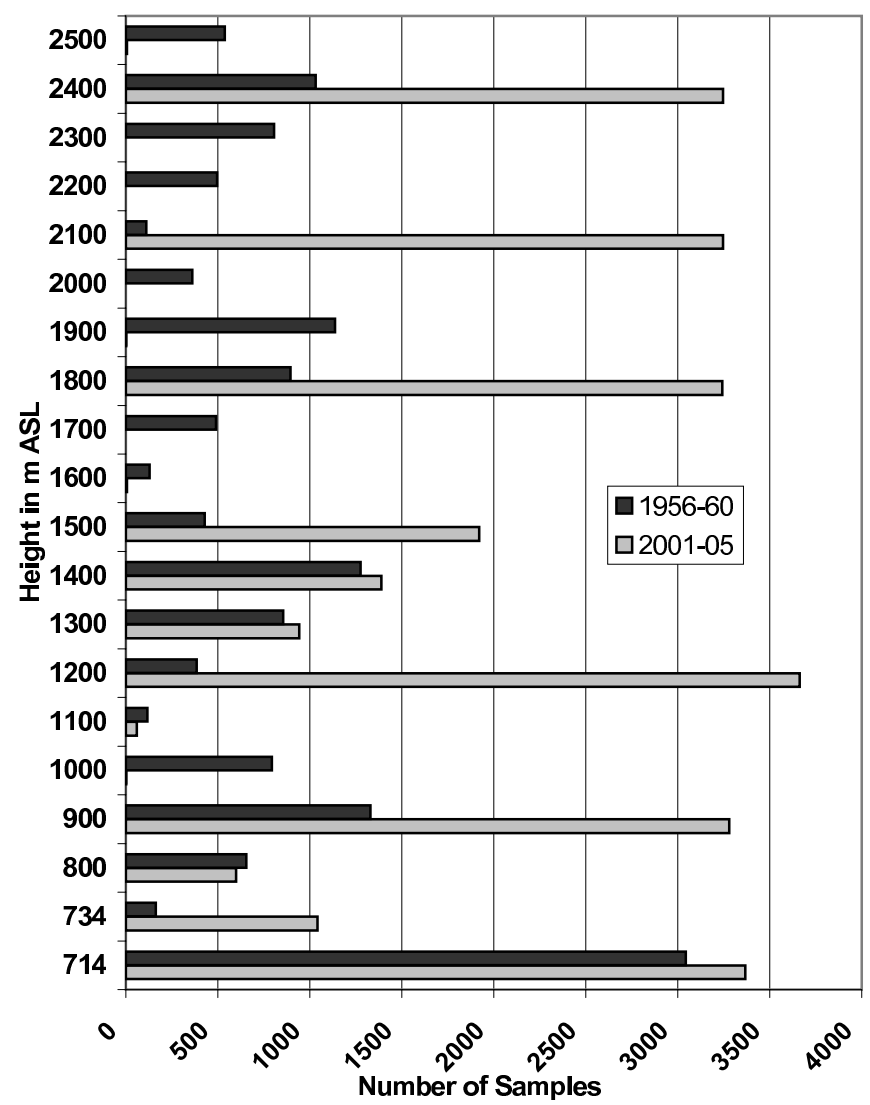

FIG. 2. Occurrence of wind speed measurements with respect to elevation for the first five and last five years of the 50-year study period. For example, in 2001-05, 3280 measurements occurred between 900 and $1000 \mathrm{~m}$ ASL.

of wind measurements at 914 and 1219 m ASL are common from 1998 on.

Although the pattern of temperature measurements was similar to that of wind speed measurements in the early part of the data set, the density and concentrations had not changed in recent years. The total number of temperature measurements actually decreased slightly between the two five-year periods. Errors in the sounding wind and temperature measurements are within $5 \%$ and $1 \%$ respectively (Golden et al., 1986). In this study, the measurements are interpolated to $100 \mathrm{~m}$ intervals. The wind speeds in the latter part of the data set are likely to be underestimated in between the $300 \mathrm{~m}$ levels. This is especially likely in the lowest $200 \mathrm{~m}$ because of local surface obstructions and the reduced number of measurements in the first few hundred metres above the surface station.

\section{UPPER-AIR TIME SERIES AND SURFACE CORRELATIONS}

Time series of annual mean wind speeds for the Whitehorse upper-air station, presented in Figure 3, show that the wind speeds have increased over the 50-year analysis period. A linear least squares method (LLSM) trend extending over the period shows the wind speeds

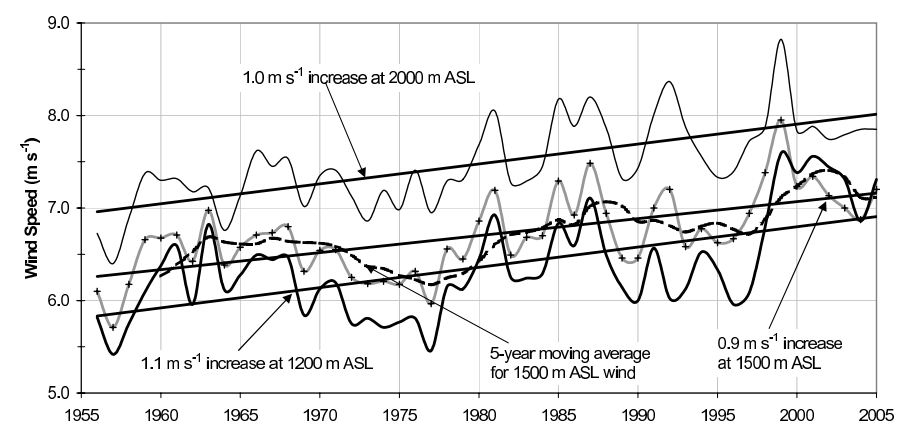

FIG. 3. Time series of annual mean wind speed at three elevations $(1200,1500$, and $2000 \mathrm{~m} \mathrm{ASL}$ ) within the Whitehorse valley. The trends at the three elevations were estimated using a linear least squares method fit to the data. A five-year moving average for the $1500 \mathrm{~m}$ ASL elevation is shown as a dashed line.

increasing by about $1 \mathrm{~m} \mathrm{~s}^{-1}\left(0.2 \mathrm{~m} \mathrm{~s}^{-1}\right.$ per decade $)$ at 1200 , 1500 , and $2000 \mathrm{~m}$ ASL. These values represent an increase in wind speed of approximately $3 \%$ per decade at these elevations. Time series for the upper-air stations at Inuvik, Norman Wells, Fort Nelson, Prince George, and Yakutat also show wind speed increases (at $1200 \mathrm{~m} \mathrm{ASL}$ ) over the last 50 years. For the same period, the annual mean temperature at Whitehorse also increased (using LLSM) by $2.7^{\circ} \mathrm{C}$ at the surface and $1.0^{\circ} \mathrm{C}$ at $2000 \mathrm{~m} \mathrm{ASL}$. Record annual mean winds of 7.6, 8.0, and $8.8 \mathrm{~m} \mathrm{~s}^{-1}$ were attained in 1999 at 1200, 1500, and $2000 \mathrm{~m} \mathrm{ASL}$, respectively. Beginning in 2000, the annual mean wind speeds at $1200 \mathrm{~m}$ ASL were higher than those at $1500 \mathrm{~m}$ ASL. The five-year (2001-05) average at $1200 \mathrm{~m} \mathrm{ASL} \mathrm{was} 7.3 \mathrm{~m} \mathrm{~s}^{-1}$ (compared to 7, 6.7, and 6.4 for the 10-, 20-, and 50-year averages, all ending in 2005). A five-year moving average of the wind speed at $1500 \mathrm{~m}$ ASL reveals local minima in 1977 and 1997 and local maxima in 1963, 1988, and 2003.

The 2001-05 monthly mean wind speeds at mid to upper elevations show minimum winds in June and July and a maximum in December (Fig. 4). January is the coldest and July the warmest month of the year, and this pattern has not changed over the 50-year period. At $10 \mathrm{~m}$ above the valley floor, or $714 \mathrm{~m} \mathrm{ASL}$, the wind speed varied slightly between 2.2 and $2.7 \mathrm{~m} \mathrm{~s}^{-1}$. The wind speed at $900 \mathrm{~m} \mathrm{ASL}(200 \mathrm{~m}$ AGL) varied from a minimum of $5.0 \mathrm{~m} \mathrm{~s}^{-1}$ in July to a maximum of $9.2 \mathrm{~m} \mathrm{~s}^{-1}$ in December. A drop in wind speed at $900 \mathrm{~m} \mathrm{ASL}$ and at the surface is noticeable in January, when the winter inversion is typically deepest. The winds at 1200 and $1500 \mathrm{~m}$ ASL reached a minimum of about $5 \mathrm{~m} \mathrm{~s}^{-1}$ in June-July and maxima of 9.9 and $9.1 \mathrm{~m} \mathrm{~s}^{-1}$ respectively in December. The mean winds at $1800 \mathrm{~m}$ ASL (not shown) were similar to those at 1200 and $1500 \mathrm{~m}$ ASL.

A local wind speed maximum, or low-level jet, is apparent in Figure 4, where monthly mean wind speeds at $1200 \mathrm{~m}$ ASL surpass those at $1500 \mathrm{~m}$ ASL from September to February. As common as these jets seem to have become in the most recent five years, they have occurred regularly over the 50-year period. From 1956 to 1999, wind speeds at $1200 \mathrm{~m}$ ASL surpassed those at 1500 in $30 \%$ of the soundings released each year. During the period 2001-05, 


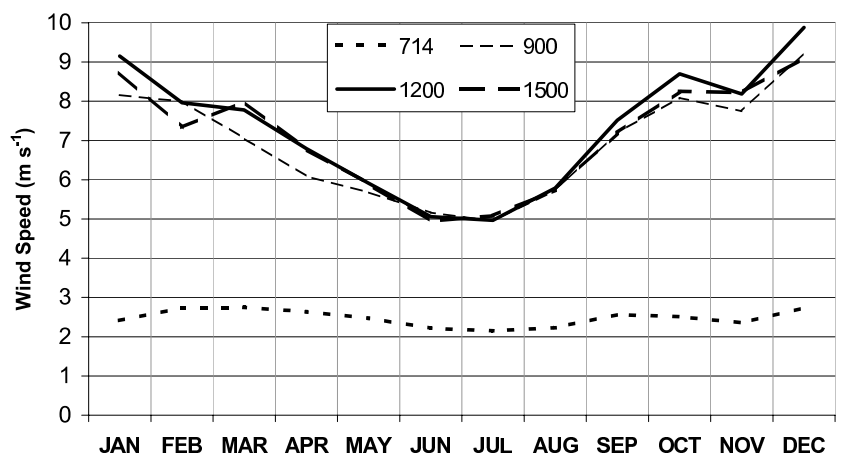

FIG. 4. Monthly mean wind speeds for the period 2001-05 at 714, 900, 1200, and $1500 \mathrm{~m}$ ASL within the Whitehorse Valley. (The elevation $714 \mathrm{~m} \mathrm{ASL}=$ 10 m AGL.)

the jet occurred in $50 \%$ of the soundings. There are at least two possible explanations for this: an increase in sounding measurements near 1200 m ASL since 1998, and a substantial increase in lower-troposphere wind speed and pressure gradient after 1997.

Measurements from the three nearby mountaintop surface stations operated by BAEC are compared to those of the upper air at similar elevations. Mount Sumanik (24 m AGL, $1700 \mathrm{~m}$ ASL), Flat Mountain (18 m AGL, $1930 \mathrm{~m} \mathrm{ASL}$ ), and upper air (1700 and $1900 \mathrm{~m})$ measurements are compared for June-August 1992 (88 days). Haeckel Hill (30 m AGL, 1430 m ASL), Mount Sumanik, and upper air (1400 and 1700) measurements are compared for August-October 1994 (61 days). The Pearson correlation (R) of the daily mean wind speed between Mount Sumanik and the upper air was 0.88 in 1992 and 0.94 in 1994. The corresponding correlation between Flat Mountain and the upper air was 0.70 in 1992; and that for Haeckel Hill and the upper air was 0.94 in 1994. Ratios of wind speeds between surface stations and the upper air were calculated as 0.95 for Haeckel Hill, 1.01 for Mount Sumanik, and 1.03 for Flat Mountain.

The surface station wind speeds were then projected to $2001-05$, using the upper air measurements as a base line. Those projections resulted in wind speed estimates of $6.9 \mathrm{~m} \mathrm{~s}^{-1}$ for Haeckel Hill, $7.5 \mathrm{~m} \mathrm{~s}^{-1}$ for Mount Sumanik, and $7.9 \mathrm{~m} \mathrm{~s}^{-1}$ for Flat Mountain. Mount Sumanik and Flat Mountain wind speeds were projected to $30 \mathrm{~m} \mathrm{AGL} \mathrm{from}$ their measurement elevations using multipliers of 1.03 for Mount Sumanik and 1.07 for Flat Mountain. These multipliers were derived from the logarithmic profile law, using $\mathrm{z}_{0}=0.01 \mathrm{~m}$. This estimate assumes a flow over a flat plain; however, it closely matches the Haeckel Hill profile. These projections resulted in wind speed ratios between surface and upper air stations of 0.95 for Haeckel Hill, 1.04 for Mount Sumanik, and 1.10 for Flat Mountain (estimated at $30 \mathrm{~m} \mathrm{AGL)}$. At $30 \mathrm{~m}$ AGL, wind speeds were estimated as $7.7 \mathrm{~m} \mathrm{~s}^{-1}$ for Mount Sumanik and $8.4 \mathrm{~m} \mathrm{~s}^{-1}$ for Flat Mountain. The Haeckel Hill measurements by Yukon Energy that were made in 1998-2001 included the year 1998 with the record annual wind speeds. Projected to 2001-05, this site's long-term mean wind speed was approximated as $6.7 \mathrm{~m} \mathrm{~s}^{-1}$.
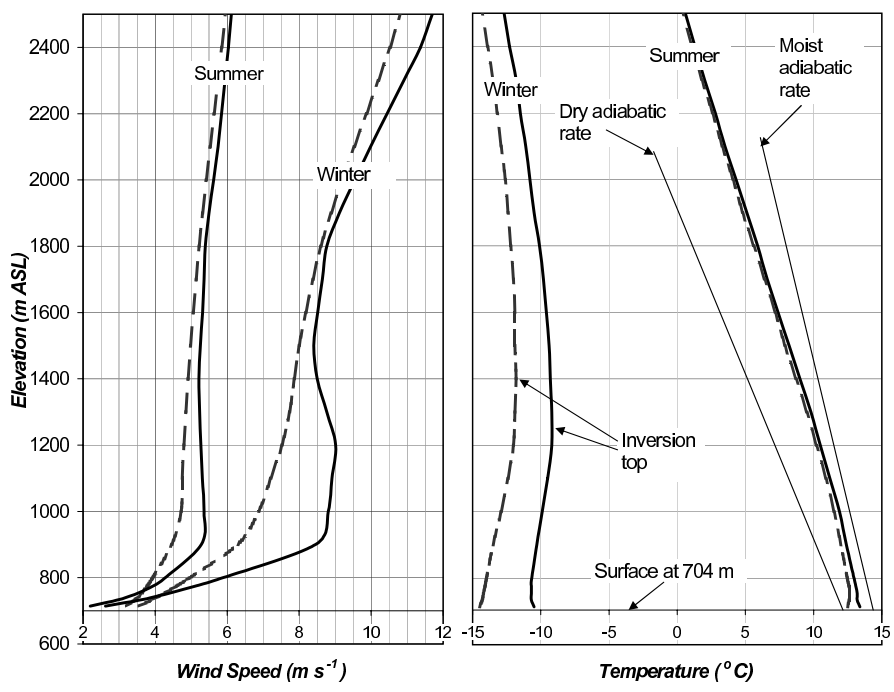

FIG. 5. Vertical profiles of winter (December, January, and February) and summer (June, July, and August) mean wind speed and temperature for the 50year period 1956-2005 (dashed line) and the five-year period 2001-05 (solid line). Graph on the right shows two reference lines: the dry adiabatic rate $\left(10^{\circ} \mathrm{C}\right.$ decrease per $1000 \mathrm{~m}$ rise) and the moist adiabatic rate $\left(6^{\circ} \mathrm{C}\right.$ decrease per $1000 \mathrm{~m}$ rise). The top of the temperature inversion (height of maximum temperature) is also identified.

\section{CLIMATOLOGICAL VERTICAL PROFILE OF UPPER-AIR WIND SPEED}

The 2001-05 annual mean wind speed above the Whitehorse station was 6.9 at $900 \mathrm{~m}$ ASL, 7.3 at $1200 \mathrm{~m}$, 7.1 at $1500 \mathrm{~m}$, and $7.3 \mathrm{~m} \mathrm{~s}^{-1}$ at $1800 \mathrm{~m}$. A local maximum annual mean wind speed is evident at $1200 \mathrm{~m}$ ASL. Using linear interpolation, the minimum wind speed of $6 \mathrm{~m} \mathrm{~s}^{-1}$ is reached at about $150 \mathrm{~m}$ above the surface, or $850 \mathrm{~m}$ ASL. In Figure 5, vertical profiles of wind speed and temperature are classified into winter (December to February) and summer (June to August) means for two periods: 19562005 and 2001-05. The graph on the left shows significant increases in mid-valley wind speeds for 2001-05 compared to the 50-year average. Note the apparent quasilinear interpolations of the January $2001-05$ profile between the surface, 900, 1200, 1500, and $1800 \mathrm{~m}$ ASL. The elevations at which most samplings occur (shown in Fig. 2) are evident here, and errors are expected to be larger between these elevations. It is therefore likely that a higher vertical density of measurements will produce different results from those described in the next paragraph.

From the 50-year to the five-year mean wind speed profiles, the maximum increases are at $900 \mathrm{~m} \mathrm{ASL}$, where the summer and winter winds show gains of $0.8 \mathrm{~m} \mathrm{~s}^{-1}$ and $2.2 \mathrm{~m} \mathrm{~s}^{-1}$ respectively. The winter profiles also show a significant increase of $1.5 \mathrm{~m} \mathrm{~s}^{-1}$ at $1200 \mathrm{~m} \mathrm{ASL}$. A lowlevel winter jet is apparent at this same elevation, and could also be said to exist in the summer profile at $900 \mathrm{~m}$ ASL. In the winter 2001-05 profile, the local maximum wind speed is $9 \mathrm{~m} \mathrm{~s}^{-1}$ at $1200 \mathrm{~m} \mathrm{ASL}$, and the local minimum is $8.4 \mathrm{~m} \mathrm{~s}^{-1}$ at $1500 \mathrm{~m} \mathrm{ASL}$. This value is slightly lower than the wind speed of $8.5 \mathrm{~m} \mathrm{~s}^{-1}$ at $900 \mathrm{~m} \mathrm{ASL}$. In the 
summer 2001-05 profile, the wind speed reaches a local minimum of $5.2 \mathrm{~m} \mathrm{~s}^{-1}$ at $1400 \mathrm{~m} \mathrm{ASL}$ and a local maximum of $5.4 \mathrm{~m} \mathrm{~s}^{-1}$ at $1000 \mathrm{~m}$ ASL. Note that at the surface the fiveyear mean wind speed is lower than the 50-year average. Mean wind speed was $4.2 \mathrm{~m} \mathrm{~s}^{-1}$ (10 m AGL) in 1955-79, but it decreased to $2.4 \mathrm{~m} \mathrm{~s}^{-1}$ in $1997-2005$, after the upperair station was relocated to its present, more sheltered location. Between 1979 and 1997, there was a significant lack of surface wind data.

The graph on the right in Figure 5 shows little change from the 50-year to the five-year mean summer temperatures, but a significant increase for winter. The summer profiles show that the mean summer atmosphere is conditionally unstable: the mean environmental lapse rates (rate at which air temperature changes with elevation) are less than the dry adiabatic rate, but more than the moist adiabatic rate. The winter profiles show that the atmosphere is absolutely stable, as the environmental lapse is less than the moist adiabatic rate. The five-year mean winter temperature, compared to the 50 -year mean, is warmer by $1.5^{\circ} \mathrm{C}$ at $2500 \mathrm{~m} \mathrm{ASL}$ and by $4^{\circ} \mathrm{C}$ at the surface. Time series (using LLSM) show that the mean surface temperature in January warmed by $9^{\circ} \mathrm{C}$ compared to less than $1^{\circ} \mathrm{C}$ in July. The winter profile for 2001-05 shows that the atmosphere below $2000 \mathrm{~m}$ ASL has become less stable. The mean elevation of the top of the wintertime temperature inversion has decreased from about $1900 \mathrm{~m}$ ASL in the late 1950s to $1200 \mathrm{~m}$ ASL in $2001-05$. For the same period, the temperature inversion (based on monthly means) was more common in December and January and was most pronounced in January. In the late 1950s, the inversion appeared over a longer period: from November to February.

\section{GEOSTROPHIC WIND-VALLEY WIND RELATIONSHIPS}

A map of the vicinity of Whitehorse is shown in Figure 6, along with wind energy-frequency roses for the upper-air and local surface stations. The roses represent the relative amounts of wind energy that occur in each direction. The wind energy frequency is calculated as the product of the percentage frequency and the cube of the mean wind speed for each direction, divided by the sum of those products in all directions. Compared to a simple wind frequency (occurrence) rose, this type of rose provides a better measure of the direction of the important wind energy. The upperair roses in the upper right corner are for the period $2001-$ 05 ; they do not vary substantially from the 50-year average.

At the bottom of the Whitehorse Valley, the Laberge, Nursery, and airport stations show predominant winds from the south-southeast, whereas the upper-air surface station shows predominant southerly winds. The airport station has the highest wind speeds of the four valleybottom surface stations and is the most exposed. The wind direction of the upper-air surface station is affected by local topography, i.e., a small treed hill to the southeast and a north-south boulevard to the south. The upper-air winds at 900 (not shown), 1200, and $1400 \mathrm{~m}$ ASL were predominantly from the south-southeast, with over $75 \%$ of the wind energy from the southeast to south. The wind directions at $1200 \mathrm{~m}$ ASL were more narrowly focused than those at elevations above and below. The largest rate of change in wind direction with elevation occurred between 1700 and $1900 \mathrm{~m} \mathrm{ASL}$. At $2500 \mathrm{~m} \mathrm{ASL}$, the wind energy was predominantly from the southwest. From 1200 to $2500 \mathrm{~m} \mathrm{ASL}$, there is a veering of about $65^{\circ}$ (clockwise looking from above) in the predominant wind direction.

Higher up in the valley, the Mount Sima station measured two main wind energy modes. One is from the southeast to the east of Mount Golden Horn (1713 m ASL) located directly south. The other mode is from the westsouthwest between Mount McIntyre and Mount Golden Horn. The Fish station measured predominant winds from the west-southwest and although it is at the same elevation, it measured roughly $80 \%$ of the wind speed at Mount Sima. At the mountaintop elevations both Haeckel Hill and Mount Sumanik measured predominant south-southeasterly winds. While Haeckel Hill showed a tendency for more southeasterly winds, Mount Sumanik, $5 \mathrm{~km}$ to the west and $300 \mathrm{~m}$ higher, measured more significant winds from the south and south-southwest. Flat Mountain, across the Takhini Valley to the north, recorded winds that were primarily from the west-southwest, with a smaller mode from south-southeast.

The relationship between the winds aloft (geostrophic, above the mountaintops) and within the Whitehorse Valley is illustrated in Figure 7, using joint wind energyfrequency roses. The winds aloft $(2400 \mathrm{~m}$ ASL) are categorized into four main wind directions, two parallel to and two perpendicular to the valley. At $900 \mathrm{~m} \mathrm{ASL}$, the resulting joint wind energy-frequency roses show that winds aloft that are perpendicular to the valley are associated with valley winds that flow to the left (facing downstream of the winds aloft). Winds aloft that were parallel to the valley were associated with valley winds flowing in the same direction. When comparing the ratios of mean winds in the valley to those aloft, there appears to be little difference between the mean valley wind speeds relative to the mean winds aloft that are south-southeast (parallel) and west-southwest (perpendicular).

Figure 8 shows that when the winds aloft are from the west-northwest, two important direction modes appear within the valley. In this figure, the roses are further classified into summer and winter. The roses show that the prevailing summer valley winds are from the north-northwest. In the winter, however, the winds are predominantly from the south-southeast. A wintertime countercurrent is evident here, and there is an apparent decoupling between the winds aloft and those in the valley.

Figure 9 provides a simple illustration of the forcing mechanisms that dominate according to the valley orientation with respect to the winds aloft. The valley that is parallel to the winds aloft experiences a forced channeling 


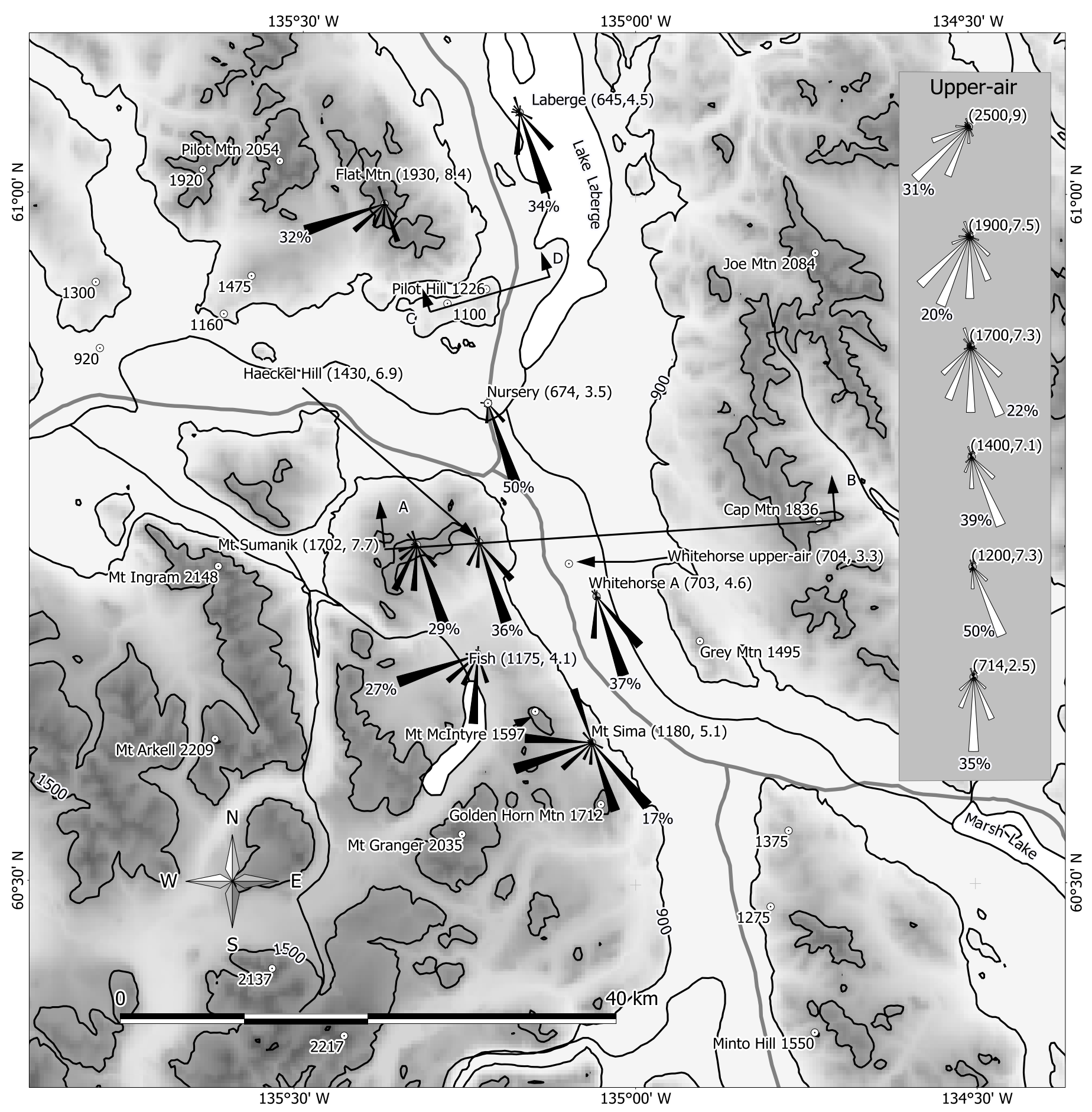

FIG. 6. A relief map of the Whitehorse vicinity shows wind monitoring stations and their wind energy-frequency roses. The length of each rose arm represents relative wind energy-frequency by direction. The wind energy-frequency is calculated as the product of the percentage frequency and the cube of the mean wind speed for each direction, divided by the sum of those products in all directions. The direction with the maximum relative energy is identified with a $\%$ sign. The numbers beside each name are the site elevation in metres ASL and the mean wind speed estimated at $30 \mathrm{~m}$ AGL. The elevation contours are at 900, 1500, and $2100 \mathrm{~m}$ ASL.

of valley winds through a downward momentum transport from the winds aloft. The valley that is perpendicular experiences winds that flow to the left (facing downwind aloft, in the Northern Hemisphere). This leftward flow is caused by high pressure to the right of the winds aloft, which drives the valley winds to the left, and it is also known as pressure-driven channeling. The right quadrant valley on
Fig. 9 is a valley oriented to the right of the winds aloft (say $-45^{\circ}$ ). In the right quadrant (in the Northern Hemisphere), the two forcing mechanisms are oriented in the same direction. In the left quadrant, however, the two forcing mechanisms oppose each other. As demonstrated in Figure 8, in the left quadrant, forced channeling is the dominant mechanism in the summer, while pressure-driven channeling 


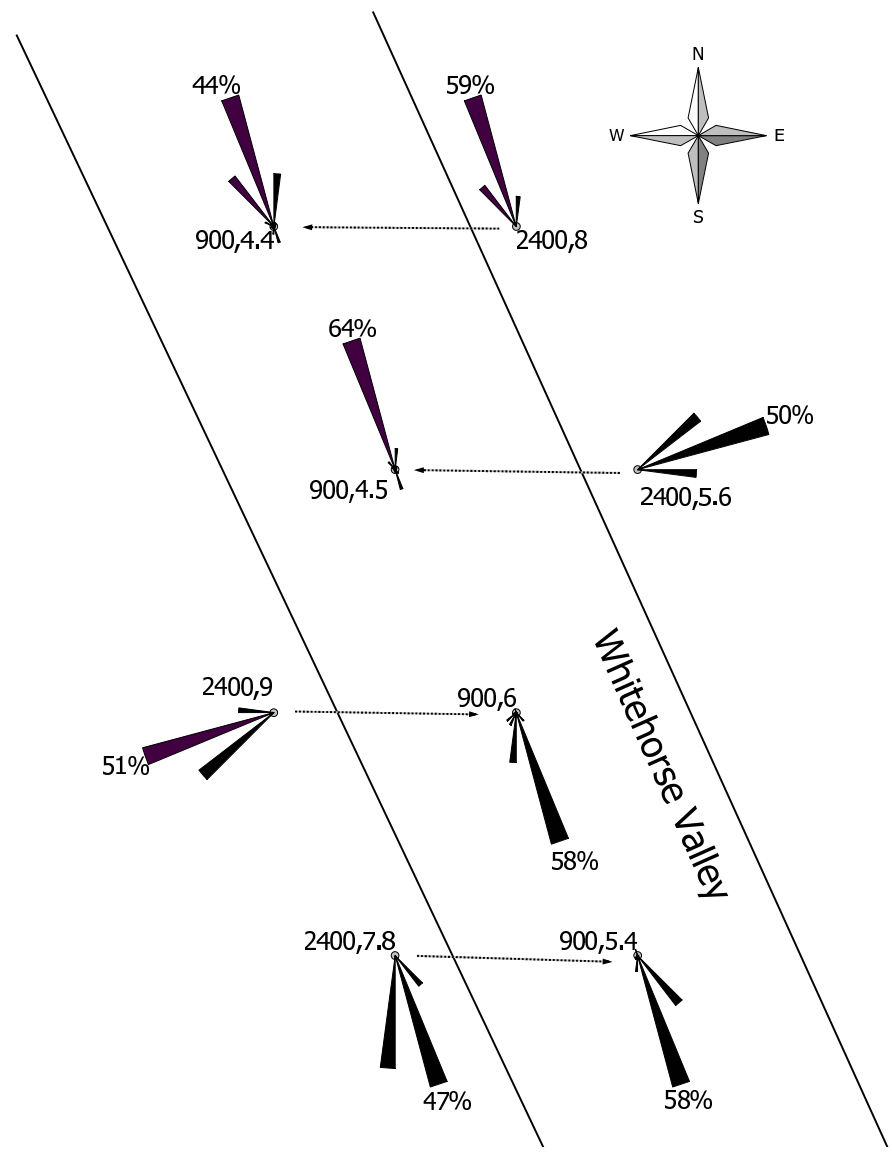

FIG. 7. Joint wind energy-frequency roses of winds aloft and within the Whitehorse Valley for the period 1956-2005. The winds at $2400 \mathrm{~m}$ ASL are categorized into four main directions with respect to the valley. For each direction (represented by three $22.5^{\circ}$ sectors) at $2400 \mathrm{~m} \mathrm{ASL}$, the joint occurrence of the wind energy-frequency at $900 \mathrm{~m} \mathrm{ASL}$ is shown within the valley outline. The valley is oriented north-northwest to south-southeast. The two numbers near the center of each rose represent the elevation and the mean wind speed for each category. At the end of the largest mode is the percentage of relative wind energy for that direction sector.

dominates in winter. It is evident here that the temperature inversion must have a greater suppressing effect on the vertical momentum transport than on the pressure gradient. In all cases however, the mean in-valley wind speed is lower in winter than in summer. Further investigation of the relationship between the depth of the temperature inversion and the geostrophic and valley winds is merited.

\section{DISCUSSION}

The positive trend in annual mean wind speed over 50 years suggests that wind farm economics are in the long run becoming more attractive. In the wintertime, the greater increase in mean wind speeds complements the seasonally higher energy demand. If the trend toward increasing wind speed continues at $3 \%$ increase per decade, then we could expect a growth in energy production of about $9 \%$ per decade. However, it is difficult to predict whether the trend will continue or has reached a climax. Since the record annual mean wind speed in 1999, there has been a

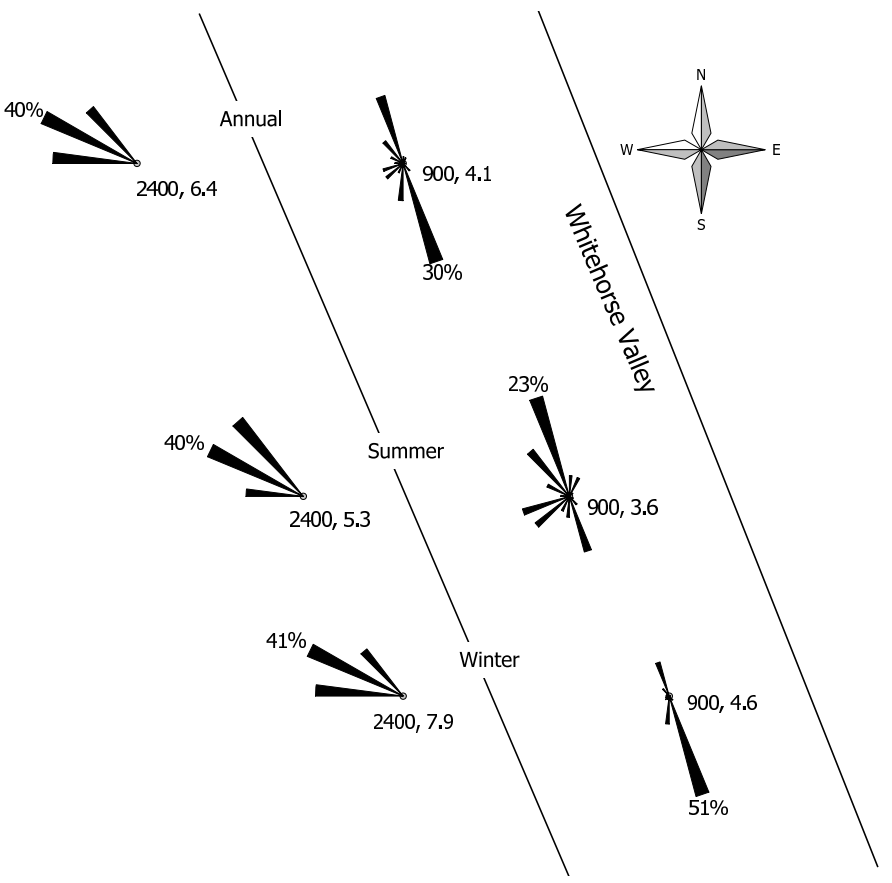

FIG. 8. Same as Figure 7, except that the winds at $2400 \mathrm{~m} \mathrm{ASL}$ are limited to 270-315 (west- northwest). The roses are classified into annual, summer (June, July, August), and winter (December, January, February).

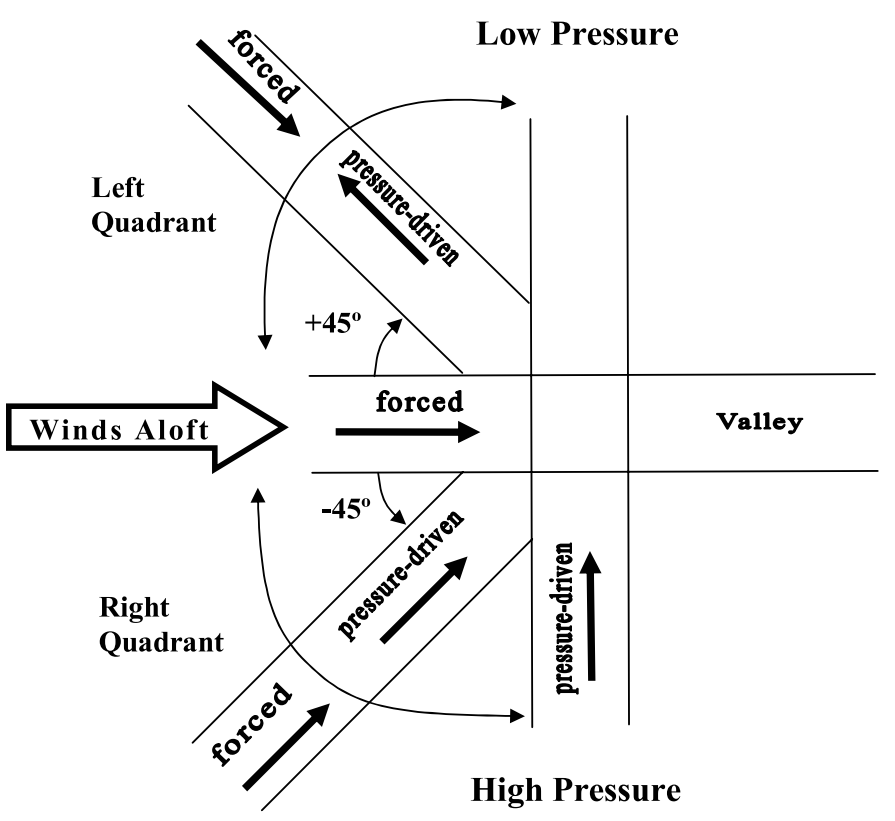

FIG. 9. A relationship between the winds aloft (geostrophic winds) and winds within a valley of various orientations. Note that "pressure-driven" is wind that is driven from high to low pressure, and "forced" refers to downward momentum transport by winds aloft.

(short-term?) decrease. The five-year moving average in Figure 3 suggests that this may be temporary. Since 1999, the increased mid-valley winds appear to be associated with a shallower winter temperature inversion. If the climate continues to warm, the temperature inversion will likely become even shallower. This will allow a greater influence of the forcing mechanisms presented earlier and hence promote higher wind speeds within the valley. 


\section{Flat Mtn $8.4 \mathrm{~m} / \mathrm{s}$}

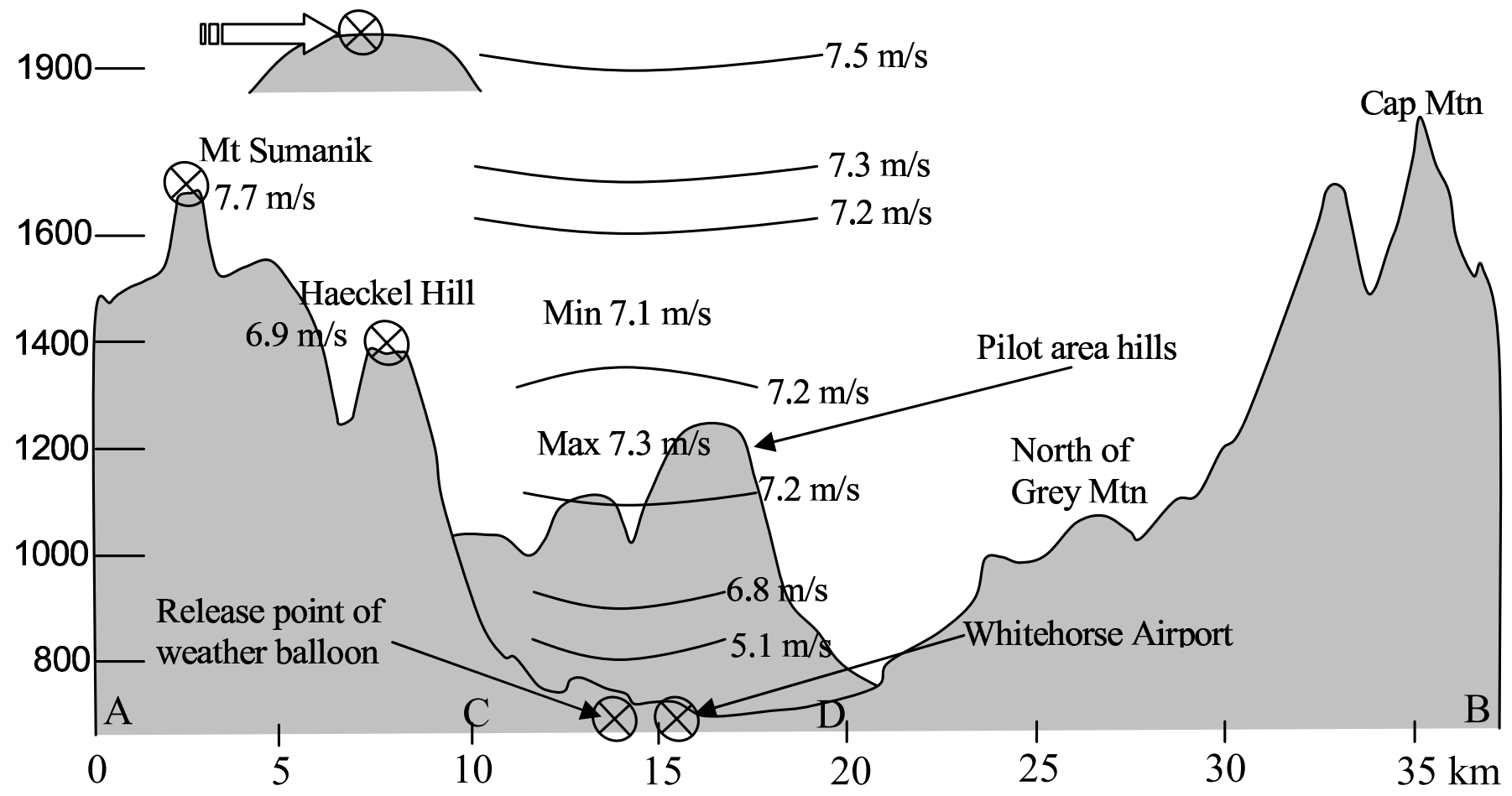

FIG. 10. Elevation profiles along lines A-B, C-D in Figure 6 of the Whitehorse area valley, with isotachs of annual mean speeds for 2001-05. Flat Mountain is $28 \mathrm{~km}$ north of Mount Sumanik and $32 \mathrm{~km}$ north-northwest of the upper-air station. The Pilot area hills (line C-D) are about $22 \mathrm{~km}$ north-northwest of the upperair station.

Figure 10 shows isotachs of annual mean wind speed overlying elevation profiles from cross-sections drawn across the Whitehorse Valley in Figure 6. It is clearly seen here that the elevation of $850 \mathrm{~m}$ ASL at which minimum annual mean wind speed $\left(6 \mathrm{~m} \mathrm{~s}^{-1}\right)$ is achieved is relatively low in the valley. Towards the center of the valley there should be greater exposure to the main valley flow. This is evident in the higher surface wind speeds measured at the airport (see Fig. 6). The Laberge station, downstream from Whitehorse, measured similarly high wind speeds. We should then expect comparably high wind speeds in the upper air over the Laberge station. The hills in the Pilot area range from 1100 to $1200 \mathrm{~m}$ ASL and could be considered prime candidates for new wind turbine sites, as they would be expected to have winds of at least $7 \mathrm{~m} \mathrm{~s}^{-1}$. It is difficult to ascertain whether the winds here would be strictly from the south-southeast, or have a component from the west.

Upstream of Whitehorse, the Mount Sima station measured relatively lower winds, and this is caused by the shadowing effect of Mount Golden Horn upstream of the station. The Fish station is also in a sheltered location, being in a bowl surrounded by mountains in all directions but the east. Haeckel Hill may possibly experience the same wind shadow effects from Mount Golden Horn (1713 m ASL) and Mount McIntyre (1598 m ASL), though less severely than Mount Sima.

Mount Sumanik is higher and more exposed, but it is still influenced by the predominant wind along the
Whitehorse Valley. The range of mountains from Mount Granger (2035 m ASL) to Mount Ingram (2148 m ASL) must act as a barrier that redirects the winds observed at Mount Sumanik and the Whitehorse Valley. Two possible causes of the relatively higher winds at Mount Sumanik are the position of the station, on a long ridge perpendicular to the prevailing winds, and the Fish Lake valley to the southeast, which allows a long reach of undisturbed wind flow upstream of the Mount Sumanik site. Upper-air measurements of prevailing wind directions at the same elevation show relatively more winds from south and south-southwest than at Mount Sumanik. The upper-air measurements are made about $10 \mathrm{~km}$ east of Mount Sumanik and so are less influenced by the orographic barrier that affects Mount Sumanik.

With the predominant winds aloft from the southwest, we ought to expect that parallel valleys will experience valley winds from the southwest by downward momentum transport. The Takhini Valley (see Fig. 1), for example, has such an orientation between Pilot Mountain and Kusawa Lake. Flat Mountain provides a clue, as its predominant wind direction is along this valley. The west-southwesterly wind at Flat Mountain may be caused by a deviation of wind flow south of the massif of Pilot Mountain (2054 m ASL), which lies $9 \mathrm{~km}$ west-northwest (see Fig. 1). The winds at $1900 \mathrm{~m}$ ASL above Whitehorse are from the southwest, being less influenced by mountain barriers. It could be concluded that within the Takhini valley, the predominant winds are predicted to be from the southwest. 


\section{CONCLUSIONS}

The Whitehorse upper-air measurements have been analyzed and found to correlate well with those from local mountaintop surface stations. The upper-air measurements indicate a 50-year increase in both temperature and wind speeds, and those increases are more profound in the winter. Above the upper-air station, viable winds occurred as low as $150 \mathrm{~m}$ above the valley floor, and a mid-valley jet was found to be a dominant feature. Winds within the valley were predominantly from the south-southeast, whereas above the mountaintops they were from the southwest. Surface stations open to the southwest recorded significant winds from those directions. Two dominant forcing mechanisms were identified: a downward momentum transport (when winds aloft were parallel to the valley axis) and a horizontal pressure gradient (when the winds aloft were perpendicular). The wintertime temperature inversion plays a role in reducing the vertical momentum transport, but winds that are dominated by or attributable to pressure-gradient forcing are affected only indirectly by stratification. Further studies are required to understand these interactions. Areas of high wind potential were identified for further exploration. Numerical modeling techniques are suggested as aids to locating sites of strong wind potential. The forcing mechanisms that drive the valley winds should be carefully considered in the parameter settings of numerical modeling.

\section{ACKNOWLEDGEMENTS}

The author would like to acknowledge the following: the Yukon Government for the surface wind data, the National Oceanic and Atmospheric Administration/National Center for Atmospheric Research Reanalysis, and RAOBS data center; John D. Wilson, supervisor at the University of Alberta; John F. Maissan, Leading Edge Inc., champion of the Haeckel Hill wind project; the Natural Sciences and Engineering Research Council, the Northern Scientific Training Program, and the Canadian Circumpolar Institute for scholarship funding; William Miller at Environment Canada, Whitehorse; Michael Purves, retired meteorologist in Whitehorse; David Craig, Joan Craig, and Jack Cable with the Boreal Alternative Energy Centre; and Sally Wright, for her love and support. This paper is dedicated to the memory of my mentor and inspiration, Doug B. Craig, pioneering wind prospector of the Yukon.

\section{REFERENCES}

AES (ATMOSPHERIC ENVIRONMENT SERVICE). 1982. Canadian climate normals, Vol. 5 1951-1980. Ottawa: Environment Canada. 283 p.

BAKER, D.R. 1991. Analysis of upper air wind speed and direction data collected at Whitehorse, Yukon, 1980 to 1989. Technical report. Nor'Wester Energy Systems Ltd., prepared for the Yukon Energy Corporation, Box 5920, Whitehorse, Yukon Y1A 6 S7.
DORMANN, C.F., and WOODIN, S.J. 2002. Climate change in the Arctic: Using plant functional types in a meta-analysis of field experiments. Functional Ecology 16:4-17.

FAULKNER, D.A. 1981. A winter-time low-level jet in a Yukon valley. Second Conference on Mountain Meteorology, American Meteorological Society, November 1981, Steamboat Springs, Colorado. 36-39.

GOLDEN, J.H., SERAFIN, R., LALLY, V., and FACUNDO, J. 1986. Atmospheric sounding systems. In: Ray, P.S., ed. Mesoscale meteorology and forecasting. Boston, Massachusetts: American Meteorological Society. 50-70.

GRAHAM, N.E., and DIAZ, H.F. 2001. Evidence for intensification of North Pacific winter cyclones since 1948. Bulletin of the American Meteorological Society 82:1869-1893.

GROSS, G., and WIPPERMANN, F. 1987. Channeling and countercurrent in the upper Rhine Valley: Numerical simulations. Journal of Climate and Applied Meteorology 26(10):1293-1304.

HARTMANN, B., and WENDLER, G. 2005. The significance of the 1976 Pacific climate shift in the climatology of Alaska. Journal of Climate 18:4824-4839.

IPCC (INTERGOVERNMENTAL PANEL ON CLIMATE CHANGE). 1998. The regional impacts of climate change: An assessment of vulnerability. Cambridge: Cambridge University Press.

KLOCK, R., HUDSON, E., AIHOSHI, D., and MULLOCK, J. 2001. The weather of the Yukon, Northwest Territories and western Nunavut: Graphic area forecast 35. Ottawa: NAV Canada. 221 p.

MAISSAN, J.F. 2001. Wind power development in sub-Arctic conditions with severe rime icing. Proceedings of the Circumpolar Climate Change Summit and Exposition, 19-21 March 2001, Whitehorse, Yukon. The Northern Review 24:174-183.

MITCHELL, J.M. 1956. Strong surface winds at Big Delta, Alaska. Monthly Weather Review 84(1):15-24.

NIKLEVA, S. 1979. Environmental data study Alaska Highway Pipeline Project report No. 1a-minisonde data analysisBurwash Landing Yukon. Technical report. Vancouver: Atmospheric Environment Service. 21 p.

- 1984. Low-level jet in the Kluane valley. Meeting on Northern Climate, April 1984, Whitehorse, Yukon. 29-30.

PINARD, J.-P. 2005. Wind climate of the mountainous Yukon. In: Castleden, H., Danby, R., Giles, A., and Pinard, J.-P. New northern lights: Graduate research on circumpolar studies from the University of Alberta. Edmonton: Canadian Circumpolar Institute. 119-156.

PINARD, J.D.J.-P., BENOIT, R., and YU, W. 2005. A WEST wind climate simulation of the mountainous Yukon. AtmosphereOcean 43(3):259-282.

WAHL, H.E., FRASER, D.B., HARVEY, R.C., and MAXWELL, J.B. 1987. Climate of Yukon. Climatological Studies 40. Ottawa: Environment Canada.

WHITEMAN, C.D., and DORAN, J.C. 1993. The relationship between overlying synoptic-scale flows and winds within a valley. Journal of Applied Meteorology 32:1669-1682. 